\title{
Debunking three myths about Madagascar's deforestation
}

\author{
Nadia R. Horning
}

\author{
Middlebury College \\ Vermont, U.S.A. \\ E-mail: nhorning@middlebury.edu
}

\begin{abstract}
After more than three decades of describing, explaining, and tackling deforestation in Madagascar, the problem persists. Why do researchers, practitioners, politicians, and farmers remain perplexed about this problem? This essay offers that our collective thinking of the past three decades has inadvertently perpetuated three myths. The first is that farmers are central agents of deforestation. The second is that the Malagasy state has the capacity and willingness to address the problem. And the third is that Madagascar is unique, especially relative to the rest of Africa. This essay examines each of these established 'truths' in an effort to overcome deforestation and all the degradation - environmental, social, and economic - that accompanies it. It argues that the assumptions behind conservation policies and projects are perpetuated by a class of powerful domestic and foreign individuals whose interests are best served by not questioning their validity. It concludes that fighting deforestation from now on must entail a deliberate, collective effort to question these assumptions and a willingness to open up the thinking to farmers and fellow Africans.
\end{abstract}

\section{RÉSUMÉ}

Le problème de la déforestation persiste à Madagascar et cela malgré les efforts acharnés des chercheurs, des professionnels du développement et de la conservation, des dirigeants politiques et des paysans qui, conjointement ou individuellement, essaient de décrire, d'expliquer et de résoudre ce problème depuis plus de trente ans. Pourquoi restent-ils donc tous désemparés face à ce sujet ? La présente analyse démontre qu'au cours des trente dernières années, nous avons collectivement commis un impair en perpétuant trois mythes. Le premier, selon nous, est d'avoir admis que les fermiers sont les principaux responsables de la déforestation. Ensuite, nous avons crû que l'État malgache avait la capacité et la volonté de remédier à la situation. Enfin, nous avons pensé que Madagascar est différente du reste de l'Afrique. Ce travail examine chacune de ces 'vérités' établies afin de mieux appréhender les problèmes de la déforestation et des dégradations environnementale, sociale et économique qui les accompagnent. Le principal argument est basé sur l'hypothèse qui veut que la politique et les projets de conservation sont défendus par une classe puissante composée à la fois de décideurs nationaux et étrangers qui ne mettent pas en question la validité de ces mythes afin de ne pas desservir leurs propres intérêts. En conclusion, pour combattre la déforestation, il faudra dorénavant remettre en question de manière collective et délibérée ces présuppositions et faire preuve de volonté pour inclure les fermiers et les Africains dans la réflexion.

After more than three decades of fighting deforestation, scholars, foreign donors, politicians, and the public at large remain puzzled as to why the problem persists in Madagascar. The creation of the journal Madagascar Conservation and Development alone attests to the fact that many scholars, domestic and foreign, have invested significant effort, if not entire careers, describing and explaining the issue. Additionally, different Malagasy governments have worked, more or less cooperatively, with foreign donors eager to lend a hand in the pursuit of saving the island's prized biodiversity. As for the Malagasy public, especially forest-dependent farmers who make up a sizeable portion of the island's population, they have adapted their livelihood strategies and living conditions to an ever shrinking resource base as land, forest resources, and water have become scarcer and scarcer for most. In a word, many have, in one form or another, pondered the question of Madagascar's persistent deforestation. Why is it, then, that we remain baffled? The answer is that our collective thinking of the past three decades has inadvertently perpetuated three myths. The first is that farmers are central agents of deforestation. The second is that the Malagasy state has the capacity and willingness to address the problem. And the third is that Madagascar is unique, especially relative to the rest of Africa. These propositions must be re-examined if we want to understand why we have not yet overcome deforestation and all the degradation that has accompanied it.

\section{MYTH 1: DESPERATE FARMERS ARE WRECKING MADAGASCAR'S FORESTS}

In Madagascar's history, farmers have often been considered lower-class citizens and they have been treated as such. In the popular discourse, rural dwellers live in remote areas that are hard to reach. To urbanites, they are distant relatives of sorts. Farmers are described as poor and uneducated folks lacking sophistication and the ability to think and act rationally (IFAD 2006). The imaginary line between the world of urbanites (i.e., les Tananariviens) and that of rural dwellers (i.e., les paysans, or tantsaha in Malagasy) has been drawn so many times that 
scholars, practitioners, and the public alike have come to think of it as real. This dichotomy has roots in French colonization because the colonial system was designed to identify and privilege indigènes most likely to become replicas of French people through a process of assimilation. since the French colonial headquarters were in Antananarivo, members of the Malagasy-cum-French elite were, for the most part, city dwellers. Consequently, the idea that les Tananariviens were different and superior to everyone else in Madagascar was born. Once colonial rule officially ended in 1960, Antananarivo continued to be a prized destination as the island's political and economic capital. Being a Tananarivien became a status symbol, one that connoted power and privilege. In this manner, les Tananariviens were imagined to pursue life goals different from those of the tantsaha. And because the sophisticated and educated were in Antananarivo, it stood to reason, somehow, that rural dwellers were not. Meanwhile, politicians became adept at using the capital vs. rural imaginary fault line to explain, and more often excuse, their failures to deliver political goods to rural areas.

Paradoxically, independent rule in Madagascar has largely consisted of seeking ways to secure foreign support to allow the state to do its job, i.e., provide a measure of security and prosperity to Malagasy citizens. Presenting farmers to foreign donors as a burden or a hindrance to development has been various governments' foolproof strategy to secure aid. Donors have bought it over and over. Of course, one cannot fault politicians for being savvy strategists. Nor can one blame foreigners for reacting to sound bites that validate their claim that assistance is perennially needed. Nowhere is this more apparent than in Madagascar's conservation politics. Exploiting the myth that forest-dependent farmers are incapable of good resource stewardship, various Malagasy governments picture them as poor, ignorant, and multiplying rapidly. In other words, farmers are a hindrance to resource conservation and a threat to development as a whole (Horning 2005). At the same time, representatives of these governments fancy themselves as rational thinkers whose scientific understanding of processes at play best positions them to devise policies, enact laws, and generally analyze the island's deforestation problems in ways deemed scientific. In this way of thinking farmers have little to teach policy makers (Sayer and Campbell 2004). In fact, where and when rural communities are found to be capable of sound resource governance, these communities are portrayed as anomalies!

Undeniably, Madagascar's rural population has swollen in the past fifty years (Index Mundi 2012). Judging from variation in literacy and numeracy rates, access to education is more challenging in rural areas than in cities. Additionally, most rural areas remain out of reach due to the deplorable state of Madagascar's infrastructure. Finally, an increasing portion of the peasantry is experiencing hardship on all measures of development (economic, social, and environmental indicators) (La Gazette de la Grande île 2012). These are the facts upon which politicians rely when they refer to rural farmers as "trapped in a spiral of environmental degradation" (Repoblikan'i Madagasikara 1990). Yet the scholarship on deforestation, especially tropical deforestation, does not firmly establish causality between demographic pressures and deforestation. Nor is there clear evidence that poverty causes deforestation. Madagascar, in fact, is one of the world's poorest countries, but its deforestation rates are not among the highest on the continent (World Bank 2012). Besides, deforestation patterns vary throughout rural Madagascar: some communities are conserving forests successfully while others are not. If all Malagasy farmers were alike, would we not observe consistent patterns of deforestation throughout rural areas? since farmers alone cannot be held responsible for deforestation, other culprits must be considered.

Evidence of alarming deforestation where tavy is practiced or where poverty is rampant, i.e., in rural areas, is routinely used to convey the gravity of the situation. The problem with concentrating on these snapshots is that doing so distracts from less noticeable yet more devastating practices, ones that involve state actors and private actors keen on profiting from exploiting Madagascar's forests. Even when such practices are denounced or broadcast, the focus is, once again, on villagers who carry out the acts of deforestation. What is easy (or convenient) to miss are two facts: first, villagers are part of the process because public officials and private actors, all acting in their personal interests, rely on them to execute their extraction plans (EIA 2010). Second, not all village farmers are involved in these schemes. Rather, a select few collaborate with outside actors to advance their status locally. Considering that a select few villagers are used, in this context, as tools of deforestation to allow powerful actors - most of whom live in cities - to profit from clearing forests, is it correct to say that farmers are the island's agents of deforestation? A more accurate way to describe and explain deforestation is thus to say that the urban rich and powerful rely on the rural powerless to exploit resources that are supposedly public, i.e., for all to enjoy, for private gain. More often than not, private actors exploit forests with the blessing of state agents who take advantage of their power positions to seek ways to profit personally. The cries against this regrettable collaboration among powerful actors strangely falls on deaf ears whenever there is talk of tackling the problem 'at its source' (Bayart et al. 1999). Instead, politicians routinely propose short-sighted solutions as if unaware of processes at play or struck by attention deficit disorder. And while everyone feigns ignorance or amnesia, forest habitats are destroyed and plant and animal species are disappearing. How much longer can we afford to dance around the truth (Jolly 2009)?

\section{MYTH 2: MIGHTY STATE CAN NEUTRALIZE RECK- LESS FARMERS}

That the Malagasy state faces chronic challenges in providing public goods and services is an understatement. Statistical and anecdotal evidence abounds to support this claim. Strangely, and despite displaying unmistakable signs of weakness, the state fancies itself as a veritable conservation Goliath, a leviathan of sorts. Forest laws and conservation policies are the clearest manifestation of this illusion of might. In reality, the Malagasy state is a lame leviathan: it hardly controls rural dwellers' behavior vis-à-vis forests. Part of the reason for the state's distorted view of its own capacity relates to the mistaken belief that it is omnipresent. Yet, throughout the island, peasants notice the state for its absence in or poor quality of service delivery, especially in health care and education but also in agricultural extension. The state's prolonged absence in remote areas has been disrupted only by occasional appearances in various forms of abuse and extortion, ranging from tax collection and forced labor recruitment in the colonial era to punishment, intimidation 
and bribe extraction since independence. As far as farmers are concerned, the state has muscles, but it flexes them in ways that hurt rather than help them live a decent life (Englebert 2009). As a consequence, villagers think it is best to avoid the state.

Lucky for them, farmers are by default autonomous since agents of the state show up in their territories sporadically, if at all. Farmers know this well. So, what do they do to protect the natural resources and meet their food, shelter, and health needs? They devise strategies to conserve forests by skillfully incorporating elements of forest legislation into their own systems of rules and norms regarding proper behavior vis-à-vis forest resources. Notwithstanding occasional rule enforcement, which usually amounts to extortion sprees, the state and its laws are largely irrelevant to forest-dependent farmers. More realistically, the institutions that govern forest access and utilization are hybrids of formal and community-devised rules. And the most effective guardians of the forest are village communities, not the state. In fact, there are multiple instances where village communities protect forests, more or less successfully, against the intrusion of state-sanctioned agents of deforestation such as logging and mining companies. In other words, forest conservation happens despite the state, not thanks to it.

considering the physical and psychological gap that separates the state from farmers (or the center from the periphery), it is puzzling that conservation models and projects are predicated on the assumption that decisions made at the national level (e.g., conservation laws) affect those made at the local level (farmers' behavior vis-à-vis forests), and vice versa. In reality, these two levels of conservation politics function in parallel, mostly disconnected ways that preclude the development of a symbiotic relationship whereby one level needs the other to function properly (Horning 2008a). Madagascar's national environmental politics are concentrated in Antananarivo and other world capitals, and they lock politicians and foreigners in a relationship of mutual dependency (Horning 2008b). At this level the state and its foreign partners negotiate the place of environmental conservation in the country's development strategies (Corson 2012). Through this process state sovereignty is compromised, but the state does not see this as harmful to its capacity and legitimacy. Hence its insistence that it has a key role to play in protecting the island's forests against its rural citizens.

Another realm of conservation politics exists at the community level. Here the rules governing forest access and uses are negotiated within communities and between communities and external actors including private interests and select representatives of the state. At this level compliance decisions reflect careful, not reckless, calculations that farmers make regarding when, how and how much to use forest resources. Three key factors motivate farmers' compliance decisions: whether (i) they perceive rules and rule enforcers to be legitimate, (ii) rule enforcement is predictable and consistent, and (iii) social cohesion is strong enough to overcome collective action problems (estimated by the degree to which local leaders are deemed legitimate). The state thinks that it has a full role to play in the first two factors because, in the minds of those who represent it, forest legislation applies (as is) and the state has the monopoly of rule enforcement. Evidence from resource-dependent communities points to the fact that both assumptions are wrong: communities go by rules-in-use that combine formal and community-devised rules and, especially where there is cohesion, they rely on their local capacities to enforce these rules. Given this reality, it is baffling that the state and its conservation partners stubbornly think that the state is in control of conservation.

\section{MYTH 3: MADAGASCAR IS UNIQUE}

In many ways, Madagascar is like no other place on earth. In terms of cultural makeup and biological richness alone, the island is undeniably unique. This uniqueness is touted and exploited to draw attention to the island's deforestation and threats to its exceptional biodiversity. Equally highlighted is the island's lack of means to tackle its own problems, invariably accompanied by pleas for outside help (Marcus and Kull 1999). External support has, so far, taken two principal forms: technical, because somehow everyone in charge assumes that the West has the knowhow, and financial because the West has the financial means to come to Madagascar's rescue. In the African context this story is disconcertingly familiar, and it strongly suggests that Madagascar's politics are anything but unique.

As it turns out, Madagascar and at least two East African countries have more in common than meets the eye. In the three countries the politics of deforestation play out at two main levels: national, where politicians and donors negotiate development policy priorities, and local, where village communities, on one hand, and public and private actors, on the other, vie for forest control. Admittedly, this sample is small, but research African colleagues and I conducted in Madagascar, Tanzania, and Uganda from 1998 to 2009 includes 170, 120, and 585 respondents from individual households, respectively. The surveys reveal that farmers across the three countries experience similar environmental challenges and react similarly to rules regulating their access and uses of forest resources.

Why does it matter that Madagascar is like the rest of Africa when it comes to its conservation politics? The reason is simple: those facing similar challenges, constraints, and opportunities are more likely to solve common problems by working together than by ignoring each other or, worse, working against each other. When African countries compete for the world powers' attention and resources, essentially they compete against each other. Inadvertently, they fall into insularism, which is the kind of thinking that precludes comparative analysis where it is both appropriate and necessary. This is not just counter-productive, it is dangerous because it reinforces divisions among us Africans and it leaves us vulnerable to foreign domination. Such words may read like a rant against neo-colonialism or environmental imperialism. This is not this essay's intention. Rather, it is an invitation to work collaboratively by opening our 'thinking club' to farmers (Keller 2009) and fellow Africans.

\section{REFERENCES}

Bayart, J.-F., Ellis, S. and Hibou, B. 1999. The Criminalization of the State in Africa. International African Institute, London.

Corson, C. 2012. From rhetoric to practice: How high profile politics impeded community consultation in Madagascar's new protected areas. Society \& Natural Resources 25, 4: 336-351. (doi:10.1080/08941 920.2011.565454)

Englebert, P. 2009. Africa: Unity, Sovereignty, and Sorrow. Lynne Rienner Publishers, Boulder, Colorado.

EIA (Environmental Investigation Agency). 2010. Investigation into the Global Trade in Malagasy Precious Woods: Rosewood, Ebony and Pallisander. Available at <http://eia-global.org/PDF/report--Madagascar--EIA--GW-forests--oct10.pdf> 
Horning, N. R. 2005. The cost of ignoring rules: Forest conservation and rura livelihood outcomes in Madagascar. Forests, Trees and Livelihoods 15, 2: 149-166. (doi:10.1080/14728028.2005.9752517)

Horning, N. R. 2008a. Madagascar's biodiversity conservation challenge: from local to national-level dynamics. Environmental Sciences 5, 2 109-128. (doi:10.1080/15693430801912246)

Horning, N. R. 2008b. Strong support for weak performance: Donor competition in Madagascar. African Affairs 107, 428: 405-431. (doi:10.1093/ afraf/adn036)

IFAD (International Fund for Agricultural Development). 2006. Republic of Madagascar: Country Strategic Opportunities Programme. Available at <http://www.ifad.org/gbdocs/eb/89/e/EB-2006-89-R-13.pdf>

Index Mundi 2012. Madagascar Rural Population Growth. <http://www. indexmundi.com/facts/madagascar/rural-population-growth> accessed 6 December 2012

Jolly, A. 2009. A letter on politics. Madagascar Conservation \& Development 4, 2: 75 .

Keller, E. 2009. The danger of misunderstanding 'culture'. Madagascar Conservation \& Development 4, 2: 82-85.

La Gazette de la Grande île. 2012. Banque Mondiale: Un regard sur I'extrême pauvreté à Madagascar. 21 June 2012. <http://www.lagazette-dgi. com/index. php?option=com_content\&view=article\&id=22998: banquemondiale-un-regard-sur-lextreme-pauvrete-a-madagascar> accessed 6 December 2012.

Marcus, R. R. and Kull, C. 1999. Setting the stage: the politics of Madagascar's environmental efforts. African Studies Quarterly 3, 2 : $1-8$.

Repoblikan'i Madagasikara. 1990. Charte de l'Environnement et ses Modificatifs, Chapter II. Available at <http://mg.chm-cbd.net/liens/ divers/charte_envt_madagascar.pdf>

Sayer, J. and Campbell, B. 2004. The Science of Sustainable Development: Local Livelihoods and the Global Environment. Cambridge University Press, Cambridge, UK.

World Bank Group. 2012. World Development Indicators. <http://data. worldbank.org/data-catalog/world-development-indicators/wdi-2012> accessed 6 December 2012 